\title{
Impact of Environmental Concern on Image of Internal GSCM Practices and Consumer Purchasing Behavior
}

\author{
Changjoon LEE ${ }^{1}$, So-Youn LIM² \\ Received: February 27, 2020. Revised: March 13, 2020. Accepted: May 05, 2020
}

\begin{abstract}
As environmental concerns continue to grow, green supply chain management (GSCM) is attracting attention as an element of competitive advantage for companies. This study examined internal GSCM practices to show how they influenced the end-point of the supply chain from the perspective of the end-consumer. It identified the effects of environmental concerns on consumer purchasing behavior mediated by the company image of internal GSCM practices. Data were collected through an email survey of Korean consumers. Reliability and validity were verified using SPSS 18.0. Cronbach's alpha, and confirmatory factor analysis. The results showed that environmental concerns had a positive impact on such practices, and the image of internal GSCM practices was found to have a significantly positive effect on consumer purchasing behavior. Companies will have to actively reflect environmental factors in their operational activities, and GSCM implementation will become a necessity. A positive image of internal environmental management and eco-design, which are key elements of internal GSCM practices, strengthened the company's eco-friendly image and ultimately affected consumer purchasing behavior. This suggests that it is important for companies to evaluate their environmental attitude and make eco-friendly products from a consumer's perspective, making it a differentiation strategy for a company in building an eco-friendly corporate image.
\end{abstract}

Keywords : Environmental Concern, Internal GSCM Image, Internal Environmental Management, Eco-Design, Consumer Purchasing Behavior

JEL Classification Code: M10, M39, O13

\section{Introduction}

Companies pioneering green innovation can develop and sell eco-friendly products at higher prices and, simultaneously, enjoy the "first mover advantage" to improve their corporate image and develop new markets (Chen, 2008). Environmental pollution and climate change, which were not revealed behind the remarkable economic growth following the Industrial Revolution in the 18th century, began attracting attention with the start of the 21 st century.

${ }^{1}$ First Author, PhD Student, Department of Logistics, Services, Operations Management, Sogang University, Seoul, Korea. Email: cjlee0825@hanmail.net

${ }^{2}$ Corresponding Author, PhD Student, Department of Global

Service Management, Sogang University, Seoul, Korea. [Postal

Address: 35 Baekbeom-ro, Mapo-gu, Seoul, Korea, 04107]

Email: limsy@sogang.ac.kr

(c) Copyright: The Author(s)

This is an Open Access article distributed under the terms of the Creative Commons Attribution Non-Commercial License (http://Creativecommons.org/licenses/by-nc/4.0/) which permits unrestricted noncommercial use, distribution, and reproduction in any medium, provided the original work is properly cited.
Consumers' environmental concerns have also generated changes in companies' strategies and operations, resulting in companies launching active marketing activities to build an eco-friendly image. However, the mere use of corporate advertising, packaging, labels, and other visible eco-friendly activities to earn consumer trust have been unsuccessful (Albayrak, Aksoy, \& Caber, 2013; Gupta \& Ogden, 2009). Previous studies found this to be a limitation, meaning that the gap between attitude and purchasing behavior prevents actual purchases. Companies are faced with the challenge of eliminating inhibiting factors and highlighting positive factors to transform consumers' increased environmental concerns into purchasing behavior.

Meanwhile, such concerns have led to an interest in companies' internal practices (Chen, 2008; D'Souza \& Taghian, 2005). Previous studies showed that image of eco-friendly firms was focused on marketing perspective or external GSCM practices. Han and Kim (2010) and Lee (2016) claimed that building an eco-friendly image from the consumer perspective emerges a marketing strategy or philosophy. Seuring and Müller (2008) argued that the 
internal GSCM practice is also necessary because previous studies see more GSCM external factors. Therefore, this study selected the B2B green supply chain management (GSCM) field to clarify the flow of consumers' environmental concerns and companies' efforts to build an eco-friendly corporate image and investigate the representative image of internal eco-friendly practices. Despite being a stage for companies' representative "green" internal practices, GSCM - previously unknown to consumers - is a concept that integrates environmental thinking into SCM (Srivastava, 2007). The image of a company's internal GSCM practices delivers knowledge and information on eco-friendly products to consumers and shows evidence of its eco-friendly practices, improves consumer trust, and enhances overall corporate image. It may be a solution for transforming consumers' environmental concerns into purchasing behavior by eliminating inhibiting factors and increasing consumer trust. This study examined the effect of consumers' environmental concerns on the image of internal GSCM practices and purchasing behavior. Previous studies on manufacturing companies' eco-friendly logistics activities measured the company performance based on internal employees. The current study examined how the image of internal GSCM practices, which used to be measured only by companies' internal performances, affected the end of the supply chain from the end consumer perspective.

This study divided GSCM, which was previously handled integrally as internal and external practices, focusing only on the former. Internal GSCM practice is a key factor influencing the successful adoption and performance of GSCM (Zhu \& Sarkis, 2004) and an antecedent variable (Zhu, Sarkis, \& Lai, 2013) that can promote the adoption of external GSCM practice. In addition, most previous studies conducted consumer awareness surveys that were limited to external GSCM practices. Reflecting on such limitations, this study examined whether the image of internal GSCM practices, which has not received the attention it deserves, influenced consumer purchasing behavior. This study may provide practical implications for the voluntary and active adoption and operation of internal GSCM practices from a consumeroriented perspective in the future, unlike previous eco-friendly supply chain activities that were adopted by companies faced with external regulations and competitive pressures.

\section{Theoretical Background}

Given the increasing importance of the environment, this study examined consumers' environmental concerns and the concepts of internal GSCM practice and consumer purchasing behavior. Based on theoretical considerations, this study explored the effects of consumers' environmental concerns on the image of internal GSCM practices and consumer purchasing behavior.

\subsection{Environmental Concern}

Environmental concerns have received significant interest over the last few centuries (Albayrak et al., 2013). Social concerns about environmental pollution and energy conservation began receiving significant attention in the 1960s (Bang, Ellinger, Hadjimarcou, \& Traichal, 2000), and consumers' environmental awareness issues began being amplified after the oil crisis of the 1970s (Hartmann \& Apaolaza-Ibáñez, 2012). Additionally, because of environmental pollution and climate changes caused by the Industrial Revolution, environmental concerns proliferated into the 21 st century, eventually resulting in movements of change in corporate operational activities and consumer behavior. Companies' eco-friendly activities began in the 1970s, and manufacturing and marketing activities emphasizing environmental aspects started in the 1980s (Sarkis, Zhu, \& Lai, 2011). Bang et al. (2000) argued that environmental concerns have led to energy savings by consumers and the use of renewable and green energy by businesses, with such changes expected to lead to investments by companies to develop and achieve ecofriendly production and secure competitive advantage.

Meanwhile, as environmental concerns grow, the production of goods that have a detrimental effect on the environment will be reduced, and it will be easy to find consumers who want to use eco-friendly companies' products (Thieme, Royne, Jha, Levy, \& McEntee, 2015). Hartmann and Apaolaza-Ibáñez (2012) argued that consumers' environmental concerns have become a decisive factor influencing the purchasing of green products. Czap and Czap (2010) also found that consumers with more environmental concerns are likely to be more involved in eco-friendly activities and purchase more green products. They argued that environmental concern is a decisive factor affecting consumer behavior and examined the conflicting relationship between environmental pollution and economic growth, participation in environmental protection, and so on. Nielsen's 2019 global consumer survey showed that more consumers would include sustainability-attributing factors in their purchasing behavior. Specifically, 73\% of respondents said they would be willing to change their spending habits to avoid harming the environment and would be willing to pay for products with recycled packaging and other ecofriendly elements (Nielsen, 2019). Carter and Rogers (2008) found that as buyers' and suppliers' environmental concerns increase, social activities such as the reduction of waste emitted or energy consumption will occur, reducing companies' operating expenses, improving the stakeholder relationships, and resulting in other positive effects. This shows that environmental concerns will affect not only consumers but also companies. As such, environmental concern not only relates to worries about environmental 
issues but is also causing changes in consumer perception and behavior as well as business operations. Furthermore, environmental issues and concerns in the future may present opportunities for sustainable management and competitive advantage.

\subsection{Image of Internal GSCM Practices}

Companies adopted just-in-time (JIT) and SCM processes in the early 20th century to pursue a two-pronged strategy of organizational efficiency and reduced environmental pollution. However, waste reduction and efforts in the environmental sector actually had a greater economic purpose of reducing unnecessary costs (Lai, Cheng, \& Yeung, 2005; Sarkis et al., 2011). As global warming began to surface, environmental issues became more prominent, resulting in companies' movements aimed at protecting the environment. The concept of GSCM has also emerged, encompassing the process from the purchase of eco-friendly raw materials and reverse logistics. Furthermore, it integrates marketing, operations, and strategy, emphasizing the environmental aspects of SCM (Sarkis et al., 2011). GSCM is a concept that integrates environmental thinking into SCM (Srivastava, 2007), whose activities are aimed at reducing or eliminating hazardous chemicals, emissions, energy, and solid wastes generated in the supply chain process from product design, resource procurement, the manufacturing process, and delivery to consumers through the end of the product's life cycle (Chin, Tat, \& Sulaiman, 2015). Green, Zelbst, Meacham, and Bhadauria (2012) defined GSCM as an integration of environmental systems with purchasing, operations, marketing, logistics, and reverse logistics. Ho, Shalishali, Tseng, and Ang (2009) and Zhu and Sarkis (2004) described GSCM as a collaborative activity with consumers and suppliers to enhance environmental sustainability in manufacturing companies.

As a framework for GSCM management activities, Zhu et al. (2013) divided GSCM into internal and external practices. The former requires the management of internal employees and suppliers for the implementation of the company's GSCM, whereas the latter requires collaboration with consumers or external stakeholders. Additionally, Zhu et al. (2013) argued that external GSCM practices should be preceded by internal GSCM practices to implement GSCM successfully. That is, the system of internal practices such as top management, eco-design, and subcontractor management should precede the implementation of external GSCM practices that inform society of the company's environmental activities. In a study of manufacturing companies in Japan, Gollagher, Sarkis, Zhu, Geng, Fujita, and Hashimoto (2010) confirmed that internal GSCM practices should precede external ones to accelerate the expansion of these. González, Sarkis, and Adenso-Díaz (2008) empirically verified that the successful establishment of internal GSCM practices leads to the positive development of external practices in the Spanish automobile supply chain. As such, internal environmental management and eco-friendly design, which are elements of the internal GSCM practice, comprise the most important stage in establishing long-term GSCM (Zhu et al., 2013). The current study examined only internal environmental management and eco-friendly design.

On the other hand, the image of an eco-friendly brand refers to a brand that consumers correlate with high environmental interests (Chen, 2010). Su, Jeong, Choi, and Kim (2015) empirically demonstrated that Company's image has positive affect upon purchase intention. Han and Kim (2010) examined the effect of the image of an ecofriendly hotel on the consumer's intention to return and found that the company's eco-friendly image had a positive effect on the consumer's behavior to buy or recommend a product. According to Chen (2008), as the consumers' environmental concerns grow, the eco-friendly image of the brand that had been established through corporate social responsibility will be limited. He also claimed that consumer interests shift to the company's eco-friendly operations in the future. In addition, the study also verified the impact of the company's eco-friendly core competencies on the eco-friendly image, mediated by the eco-friendly products and process innovation. It was also argued that eco-design and packaging became a differential advantage and would eventually become a competitive advantage. Consumers' environmental concerns affect the image of internal GSCM practices, which can help build the company's eco-friendly image, which in turn affects consumer purchasing behavior.

\subsubsection{Internal Environmental Management}

Internal environmental management refers to cross functional cooperation for environmental improvements within the organization, total quality environmental management, and environmental compliance and auditing programs, which need the dedication and support of middle- and high-level managers as well as environmental improvements (Zhu \& Sarkis, 2004).

Green et al. (2012) argued that the dedication of managers for successful SCM within the organization could go beyond the success of the SCM and result in the organization's success. They argued that environmentallyoriented organizational management by middle- and highlevel managers could drive the demand for environmentallyfriendly services, products, and processes from consumers and the government. Zhu and Sarkis (2004) empirically demonstrated that the dedication and support of senior management is a factor determining the success or failure of the GSCM. Because GSCM requires extensive organizational effort, top management's support, rewards, training, and 
communication are described as factors that can encourage cross functional cooperation and implementation within the organization (Zhu, Sarkis, Cordeiro, \& Lai, 2008a).

Cross-functional cooperation for environmental improvements within the organization is also a major internal GSCM practice. Zhu, Sarkis, and Lai (2019) argued that cross-functional cooperation is the driving force behind GSCM. They argued that GSCM practices and audits by subcontractors associated with the company's supply chain should be conducted within internal management practices. Lewis and Harvey (2001) also suggested that crossfunctional collaboration for the successful implementation of internal GSCM practices is an important factor. In addition, they argued that the success or failure of cross-functional collaboration and total quality environmental management, which are factors of a company's internal environmental management, depend entirely on the support of middle- and high-level managers. Furthermore, continuous environmental improvement activities and comprehensive environmental quality management factors contribute to improving the company's environmental performance as factors of internal environmental management (Gunasekaran, Lai, \& Cheng, 2008).

\subsubsection{Eco-Design}

Eco-design is the process of reducing or eliminating stages that are harmful to the environment at the product's design stage (Zhu et al., 2019). Zhu, Sarkis, and Lai (2008b) defined eco-design as a stage in which manufacturers can minimize energy and raw material consumption. They also defined it as a stage in which reuse, recycling, and recovery can be made easier, and the generation of hazardous substances in the production process can be reduced. Since eco-design focuses primarily on technological improvements that reduce environmental costs at the product and process level, cross-functional cooperation within the organization is important for a successful eco-design (Zhu et al., 2008a).

Srivastava (2007) considered eco-design an activity that includes environmentally-conscious design and life-cycle analysis, the goal of which was to develop the aspect of how much the product will affect the environment. Eco-design can be considered a process of systematically designing a healthy and safe environment for a product's entire lifecycle, including the development of new products and processes, which covers a range of regulations and principles, environmental risk management, product safety, health, pollution prevention, resource conservation, and waste management (Srivastava, 2007). Zhu et al. (2008a) defined the eco-design stage as comprising three factors: product design (1) to reduce materials and energy consumption; (2) to facilitate easy reuse, recycling, and recovery of materials and components; and (3) to avoid or reduce the generation of hazardous substances in the manufacturing process. Furthermore, Zhu, Sarkis, and Geng (2005) argued that the prevention of environmental pollution through the product design and environmental processes was the most effective way to reduce the environmental impact.

\subsection{Consumer Purchasing Behavior}

Environmental news is an important concern for both businesses and consumers. Consumers' consciousness of the must protect the environment from ongoing destruction and pollution of the natural ecosystem is changing consumer behavior to include green and ethical consumption (Moisander, 2007). Im, Song, and Chu (2019) claimed that one purchase of eco-friendly products by consumers has a long eco-friendly effect.

Consumers' purchasing preferences are also changing as interest in environmental protection and ethics continues to increase (Yadav \& Pathak, 2017) with more consumers choosing to purchase eco-friendly products, particularly those made by environmentally-conscious companies (Han $\&$ Kim, 2010). The higher the eco-friendly brand image, the more enjoyable the experience of consuming eco-friendly products is for the consumer who is eager and interested in protecting the environment (Chen, 2010). Choi, Lee, and Yang (2014) stated that when consumers purchase from companies that have an eco-friendly image, the consumers also build the image of green consumers. Moser (2015) argued that the phenomenon of increasing the general consumer's awareness about sustainability and increasing consumers' decisions to purchase eco-friendly products is an opportunity to create a new business beyond simply manufacturing eco-friendly products. In addition, Lin and Huang (2012) and Liobikienè, Mandravickaite, and Bernatonienè (2016) suggested that the factors that determine the behavior and habits of consumers who do not want to harm the environment could promote environmentally-friendly activities of stakeholders such as manufacturers, marketers, and legislators. Thiemeetal. (2015) empirically verified that consumers' environmental concerns affected environmental involvement, which in turn affected consumer behavior, mediated by the willingness to pay more. Han and Kim (2010) argued that environmental concerns and awareness are the main drivers of change in consumer purchasing behavior and attitudes, and more consumers will demand companies' environmental responsibility in the future. Furthermore, consumers' eco-friendly consumption will transform into an interest in whether the company's environmental decisions are considered in internal activities such as material purchase, manufacturing process, and work process (D'Souza \& Taghian, 2005).

On the other hand, Saifullah, Kari, and Ali (2017) argued that green technology does not factor influencing the environmental concern. Gupta and Ogden (2009) also 
claimed that, except for environmental benefits, consumers' eco-friendly purchasing behavior should be sacrificed regarding personal inconvenience, expensive costs, etc., and uncertainty about the brand and distrust will lead to action and create a gap because of the trade-off of attitude and behavior. Albayrak et al. (2013) presented differing results from Thieme et al. (2015), arguing that while consumers' environmental concern is obviously a determining factor in consumer behavior, consumers' skepticism will also play a role in mediating behavior. Factors of skeptical attitude include distrust of eco-friendly products, labels, and advertisements as well as insincere corporate advertisements. To transform consumers' high environmental concerns into consumer purchasing behavior, it is necessary to identify and eliminate factors that hinder such behavior and highlight factors that increase it. Companies must emphasize their authentic and sincere interest of the green image (Lee \& Hong, 2019) in improving the environment by raising the companies' image of internal GSCM practices, thereby enhancing consumer knowledge and trust of their products, rather than focusing on superficial packaging, certification marks, and advertisements claiming that products are ecofriendly. Table 1 below conceptualizes the variables through a theoretical review based on previous research.

\section{Hypotheses and Research Model}

Environmental concern is an important factor in consumer purchasing behavior (Thieme et al., 2015). As consumers become more concerned about the company's eco-friendly internal operations management, the company image of internal GSCM practices is also expected to influence consumer purchasing decisions. Reflecting this trend, this study examined how consumer's environmental concern affected consumer purchasing behavior mediated by the image of internal GSCM practices.

\subsection{Environmental Concern and Internal Environmental Management Image}

Several studies have examined the impact of consumers' environmental concern on corporate strategy and operational activities (Bang et al., 2000; Lin \& Huang, 2012; Liobikienè et al., 2016). Han and Kim (2010) argued that a company's eco-friendly image is important and necessary because environmental concern positively affects consumer purchasing behavior and word-of-mouth communication. D'Souza and Taghian (2005) argued that, to improve a company's green image, it must show evidence that its products are not harmful to the environment. This is because the higher the consumer's environmental concerns are, the more likely the consumer will distrust companies' eco-friendly advertisements. This is consistent with other
Table 1: Constructs of the variables

\begin{tabular}{|c|c|}
\hline Variable & Environmental concern \\
\hline Source & $\begin{array}{l}\text { Hartmann \& Apaolaza-lbáñez (2012); } \\
\text { Thieme et al. (2015); Kilbourne \& } \\
\text { Pickett (2008) }\end{array}$ \\
\hline \multirow[t]{3}{*}{ Constructs } & $\begin{array}{l}\text { Sensitivity about climate-change issue, } \\
\text { awareness of clean energy, alternative } \\
\text { energy sources, and energy } \\
\text { conservation constitute explicit }\end{array}$ \\
\hline & $\begin{array}{l}\text { Reflects consumer concern for } \\
\text { wildlife, waste, and energy }\end{array}$ \\
\hline & $\begin{array}{l}\text { Definition that includes attitudes, values, } \\
\text { and folk wisdom for environmental }\end{array}$ \\
\hline Variable & Internal environmental management image \\
\hline Source & $\begin{array}{l}\text { Zhu et al. (2005); Zhu et al. } \\
\text { (2008a); Zhu et al. (2013) }\end{array}$ \\
\hline \multirow{3}{*}{ Constructs } & $\begin{array}{l}\text { Senior manager's support to adoption } \\
\text { and implementation of innovations, } \\
\text { technology, programs, and activities. }\end{array}$ \\
\hline & $\begin{array}{l}\text { Support such as commitment from } \\
\text { senior managers, cross-functional } \\
\text { cooperation, and eco-design to be } \\
\text { successfully implemented }\end{array}$ \\
\hline & $\begin{array}{l}\text { Support to associate with the success } \\
\text { of information technology diffusion } \\
\text { within organizations }\end{array}$ \\
\hline Variable & Eco-design \\
\hline Source & $\begin{array}{l}\text { Zhu \& Sarkis (2004); } \\
\text { Zhu et al. (2008a); Zhu et al. (2013) }\end{array}$ \\
\hline \multirow{4}{*}{ Constructs } & $\begin{array}{l}\text { Design for products for reduced } \\
\text { material and energy consumption }\end{array}$ \\
\hline & $\begin{array}{l}\text { Design for the reuse, recycle, and } \\
\text { recovery of material, component parts }\end{array}$ \\
\hline & $\begin{array}{l}\text { Design of products to avoid or } \\
\text { reduce hazardousness of products }\end{array}$ \\
\hline & $\begin{array}{l}\text { Primarily on technical } \\
\text { improvements to products and } \\
\text { process to mitigate environmental }\end{array}$ \\
\hline Variable & $\begin{array}{l}\text { Consumer purchasing } \\
\text { (eco-friendly product) behavior }\end{array}$ \\
\hline Source & $\begin{array}{l}\text { Bang et al. (2000); Liobikiené et al. (2016); } \\
\text { Yadav \& Pathak (2017) }\end{array}$ \\
\hline \multirow{3}{*}{ Constructs } & $\begin{array}{l}\text { Environmental attitude and perception } \\
\text { of environmentally friendly behavior }\end{array}$ \\
\hline & $\begin{array}{l}\text { Behavior that damages the } \\
\text { environment as little as possible or } \\
\text { even benefits the environment }\end{array}$ \\
\hline & $\begin{array}{l}\text { Beliefs about the perceived personal, } \\
\text { environmental benefits of green } \\
\text { products and positive consequences of }\end{array}$ \\
\hline
\end{tabular}


studies that found that high environmental concerns do not necessarily lead to purchasing of eco-friendly products because of distrust of advertising and lack of information (Albayrak et al., 2013; Gupta et al., 2009).

These studies suggest that consumers with increased environmental concerns will no longer be persuaded by advertisements or media and will shift their attention to the company's eco-friendly internal operational activities. In addition, the internal GSCM environmental management image, which consumers had not seen, is expected to reduce the distrust of eco-friendly products and provide proof that the company has achieved results in environmental activities. In particular, the company's internal environmental management image is considered a factor that can increase consumer purchasing behavior because this image can only be achieved through the top management's efforts and dedication to suppliers to support, monitor, and compensate for environmental improvements. This study derived the following hypothesis:

Hypothesis 1: Consumers' environmental concerns have a positive effect on the company's internal environmental management image.

\subsection{Environmental Concern and Eco-Design Image}

Eco-design is defined as a representative internal GSCM practice, along with corporate internal environmental management (Zhu et al., 2008a). Berchicci and Bodewes (2005) argued that environmental concerns affect the successful product development process mediated by collaboration and support within the company. They argued that environmental concern is a strong motivation to strengthen the company's product design phase. They showed that environmental concerns affect companies' internal activities and internal environmental management and eco-friendly design are not separate activities, but are connected with one other. Knight and Jenkins (2009) stated that the eco-design stage was the only way to protect the environment from contaminants in the production process. Because eco-design covers a wide range of areas such as environmental regulation, pollution prevention, and resource management (Srivastava, 2007), it is expected to become an important factor in proving the company's ecofriendly internal activities. That is, environmental concerns affect the company's internal GSCM practices and are expected to affect the image of eco-design. This removes or reduces factors that cause environmental pollution during the manufacturing process, thereby clearly showing the environmental impact. Based on previous studies, the following hypothesis was established:
Hypothesis 2: Consumers' environmental concerns have a positive effect on the company's eco-design image.

\subsection{Internal Environmental Management Image and Consumer Purchasing Behavior}

The company's eco-friendly image has a positive effect on consumer purchasing behavior and word-of-mouth communication (Han \& Kim, 2010). Han and Kim (2010) verified that the overall image of an eco-friendly hotel significantly influenced the consumer's intention to return. In particular, it was suggested that the company's internal practices for environmental improvement, such as recycling and reduced energy consumption, should be advertised as an efficient strategy for enhancing the hotel's eco-friendly image. The internal environmental management that is implemented can affect the company's eco-friendly image. Zhu et al. (2013) suggested that significant dedication and effort within the organization is necessary for the company's external environmental management. They also argued that the full commitment, support, and communication of internal managers are essential for the company's outstanding environmental performance, which is also the key to successful internal environmental management. Additionally, such factors ultimately affect the relationship between suppliers and consumers (Zhu et al., 2013). Based on this, it can be seen that the internal environmental management will affect the company's environmental image. Therefore, companies' internal environmental management image will affect their eco-friendly image, which can be expected to further influence consumer purchasing behavior; the following hypothesis is therefore formulated.

Hypothesis 3: A company's internal environmental management image has a positive effect on consumer purchasing behavior.

\subsection{Eco-Design Image and Consumer Purchasing Behavior}

With increasing environmental concerns, eco-friendly factors will become decisive factors in the process of a consumer choosing to buy a product (Hartmann \& Apaolaza-Ibáñez, 2012). Companies have reflected on this trend and built an eco-friendly image via packaging, labels, advertisements, and other superficial activities. However, previous studies discovered that advertising-based ecofriendly activities also increased consumer distrust and skepticism and had a lower impact on their eco-friendly image (Albayrak et al., 2013). In addition, this is considered one of the causes of the "gap between attitude/purchase" of consumers who do not purchase eco-friendly products 
despite increased environmental concerns. This study explored eco-design image, which is an internal GSCM practice, as a strategy for building an eco-friendly image. Jung (2015) explained that innovative eco-friendly packages in corporate technology in FedEx.

Chen (2008) verified the innovation performance of ecofriendly products and processes as an antecedent variable impacting the eco-friendly image. That is, the eco-design phase - designed to save energy, prevent pollution, and reduce waste and hazardous materials in the production process - affects the company's eco-friendly image. This study showed that the eco-design affects this image. Chen (2010) argued that the image of an eco-friendly design would be instrumental within the company as consumers' environmental concerns increase, which can affect consumer satisfaction and trust. Eco-design, which was not shown to consumers as a company's internal practice, can be used to prove that the company is actually practicing environmental protection because the environmental impact of the ecodesign can be far-reaching. As consumer concerns shift from external to internal activities (D'Souza \& Taghian, 2005), the company's eco-design image will eventually strengthen its eco-friendly image and affect consumer purchasing behavior, as shown in Hypothesis 4.

Hypothesis 4: A company's eco-design image has a positive effect on consumer purchasing behavior.

Figure 1 shows the research model.

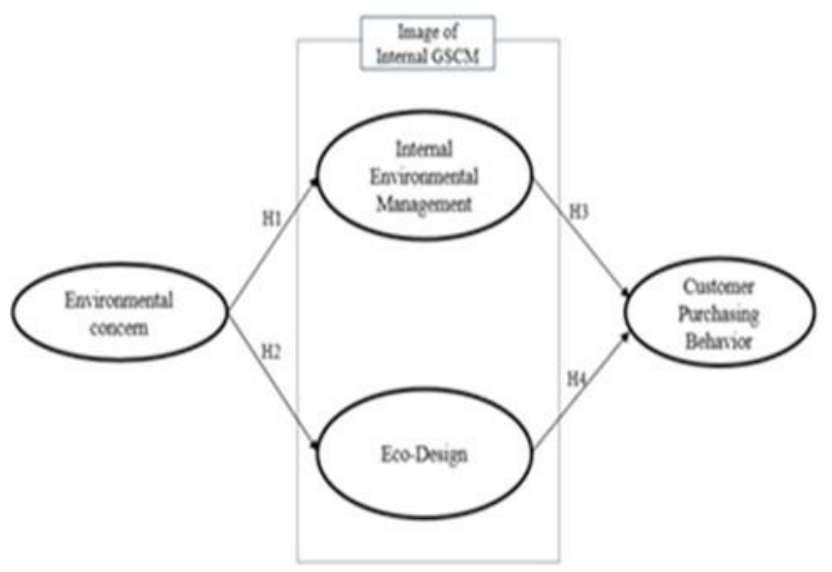

Figure 1: Research model

\section{Research Method}

\subsection{Data Collection and Sample Characteristics}

The empirical data used to verify the research model were collected through an email survey of Korean consumers. It was conducted from October to November 2019 via the website of the survey agency, "Entrust." For the survey, 575 copies were distributed, and 300 valid responses were used for statistical analysis. The survey questions consisted of demographic factors and variables developed based on existing studies. The characteristics of the sample are shown in Table 2. Half of the respondents were in their teens and 20s $(50 \%)$, and more than half were single $(63 \%)$. In addition, $66.9 \%$ had an average monthly shopping expenditure of 500,000 won or less, $16.0 \%$ spent 1 million won or less, and $17.1 \%$ spent 1 million won or more. The results revealed the majority of the respondents were young and unmarried, and their average monthly shopping expenditure was relatively low.

\subsection{Measurement of Variables}

To overcome the limitations of previous studies, which were limited to internal employees because of the characteristics of the B2B GSCM, this study expanded the survey scope to general consumers. The survey questions were designed by referring to GSCM components that are currently being measured in companies. In addition, as it may be impossible to make objective judgments from the consumer's viewpoint because of the lack of professional knowledge and information on GSCM practices, the survey items were based on the GSCM elements currently being considered. In other words, the survey focused on the "image of internal GSCM practices" (i.e., from a consumer perspective), rather than "internal GSCM practices" (i.e., from an internal employee perspective). Environmental concern was used as the independent variable and four modified measurement items from Hartmann and ApaolazaIbáñez (2012), Junior, Da Silva, Gabriel, and De Oliveira Braga (2015), Kilbourne and Pickett (2008), and Suki (2016)

Table 2: Sample characteristics

\begin{tabular}{|c|c|c|c|}
\hline & Range & Frequency & Percentage \\
\hline \multirow{3}{*}{ Age } & $10-29$ & 150 & $50 \%$ \\
\hline & $30-40$ & 110 & $36.7 \%$ \\
\hline & 50 onward & 40 & $13.3 \%$ \\
\hline \multirow{2}{*}{ Married } & Yes & 111 & $37 \%$ \\
\hline & No & 189 & $63 \%$ \\
\hline \multirow{2}{*}{ Children } & Yes & 91 & $30.3 \%$ \\
\hline & No & 209 & $69.7 \%$ \\
\hline \multirow{3}{*}{$\begin{array}{l}\text { Average } \\
\text { monthly } \\
\text { shopping } \\
\text { expenditure }\end{array}$} & $\begin{array}{l}\text { Less than } \\
500,000 \text { won }\end{array}$ & 201 & $66.9 \%$ \\
\hline & $\begin{array}{c}\text { Between } \\
500,000 \text { and } \\
1 \text { million won }\end{array}$ & 48 & $16.0 \%$ \\
\hline & $\begin{array}{c}\text { More than } \\
1 \text { million won }\end{array}$ & 51 & $17.1 \%$ \\
\hline
\end{tabular}


Table 3: Operational definitions of variables

\begin{tabular}{|c|c|}
\hline Variable & Environmental concern \\
\hline References & $\begin{array}{l}\text { Hartmann \& Apaolaza-lbáñez (2012); Junior et al. (2015); Kilbourne \& Pickett (2008); } \\
\text { Suki (2016) }\end{array}$ \\
\hline \multirow{4}{*}{ Measurement item } & The degree to which environmental concern is increasing \\
\hline & The degree of anxiety when receiving news of environmental pollution \\
\hline & The degree to which you think that life changes because of environmental pollution \\
\hline & $\begin{array}{l}\text { The degree to which you think that the products of a company that does not consider the } \\
\text { environment are more polluting }\end{array}$ \\
\hline Variable & $\begin{array}{l}\text { Internal environmental } \\
\text { management image }\end{array}$ \\
\hline References & $\begin{array}{l}\text { Zhu \& Sarkis (2004); } \\
\text { Zhu et al. (2005); } \\
\text { Zhu et al. (2008a); } \\
\text { Zhu et al. (2008b) }\end{array}$ \\
\hline \multirow{4}{*}{ Measurement item } & $\begin{array}{l}\text { The degree to which you think that employees are making significant efforts in eco-friendly } \\
\text { management }\end{array}$ \\
\hline & $\begin{array}{l}\text { The degree to which you think that the company is exercising quality control in eco-friendly internal } \\
\text { facilities }\end{array}$ \\
\hline & $\begin{array}{l}\text { The degree to which you think that there will be a supervisory program to comply with environmental } \\
\text { protection legislation }\end{array}$ \\
\hline & $\begin{array}{l}\text { The degree to which you think that the company has acquired eco-friendly management certification } \\
\text { (ISO 14001) }\end{array}$ \\
\hline Variable & Eco-design image \\
\hline References & $\begin{array}{l}\text { Zhu \& Sarkis (2004); } \\
\text { Zhu et al. (2005); } \\
\text { Zhu et al. (2008a); } \\
\text { Zhu et al. (2008b) }\end{array}$ \\
\hline \multirow{5}{*}{ Measurement item } & The degree to which you think that the packing is being simplified \\
\hline & $\begin{array}{l}\text { The degree to which you think that the company is engaged in activities to reduce energy } \\
\text { consumption }\end{array}$ \\
\hline & The degree to which you think that the company is recycling resources and energy \\
\hline & The degree to which you think that the company is reducing waste \\
\hline & The degree to which you think the company is reducing harmful emissions \\
\hline Variable & $\begin{array}{l}\text { Consumer purchasing } \\
\text { (eco-friendly product) behavior }\end{array}$ \\
\hline References & $\begin{array}{l}\text { Chan (2001); Lee (2008); } \\
\text { Yadav \& Pathak (2017) }\end{array}$ \\
\hline \multirow{4}{*}{ Measurement item } & The degree to which you purchase eco-friendly products in consideration of environmental pollution \\
\hline & The degree to which you have had a good experience in using an eco-friendly product in the past \\
\hline & $\begin{array}{l}\text { The degree to which you would select an eco-friendly product if you had to choose between an eco- } \\
\text { friendly product and a generic product }\end{array}$ \\
\hline & The degree to which you prioritize purchasing products with eco-friendly certification indicators \\
\hline
\end{tabular}

Table 4: Confirmatory factor analysis and convergent validity test results

\begin{tabular}{|l|c|c|c|}
\hline Factor & Cronbach's alpha & AVE & CR \\
\hline Environmental concern & 0.751 & 0.511 & 0.757 \\
\hline Internal environmental management image & 0.820 & 0.583 & 0.806 \\
\hline Eco-design image & 0.784 & 0.567 & 0.796 \\
\hline Consumer purchasing behavior & 0.837 & 0.547 & 0.783 \\
\hline
\end{tabular}


were utilized. The four measurement items used for the company's internal environmental management image and five for eco-design image followed Zhu and Sarkis (2004), Zhu et al. (2005), Zhu et al. (2008a), and Zhu et al. (2008b). Consumer purchasing behavior, which is the outcome variable, utilized measurement items from Chan (2001), Lee (2008), and Yadav and Pathak (2017). Respondents were asked to subjectively assess the four items on a 7-point scale, from 1 "not at all" to 7 "very much so."

\subsection{Reliability and Validity Tests}

The reliability and validity of the variables were verified using SPSS 18.0. Cronbach's alpha was used to ensure internal consistency. The results indicated that reliability was not a problem (environmental concern $=0.751$, internal environmental management image $=0.820$, eco-design image $=0.784$, consumer purchasing behavior $=0.837$ ) (Hair, Black, Babin, \& Anderson, 2010).

Confirmatory factor analysis of the measurement model was performed using AMOS 18.0. The goodness-of-fit of the measurement model was $\mathrm{CMIN} / \mathrm{DF}=1.623, \mathrm{RMR}=$ 0.048 , GFI $=0.963$, CFI $=0.982$, TLI $=0.973$, RMSEA $=0.046$, which satisfied the overall acceptable criteria (Hair et al., 2010). Construct reliability (CR) and average variance extracted (AVE) were examined to confirm the convergent validity of the concepts. The AVE values of the measurement items were all over 0.5 and the $C R$ values were 0.7 or more, indicating that there was no problem with convergent validity. The results of the confirmatory factor analysis and convergent validity tests are presented in Table 4.

Finally, to verify the discriminant validity, the AVE for each variable was measured and the correlation coefficient between the variables was calculated. The criterion for evaluating discriminant validity is that the square of the mean variance extraction value (AVE) of each latent variable should be greater than the correlation coefficient value among the latent variables. Table 5 reports the square root of AVE values of the latent variable and compares the correlation coefficients between different variables. In addition, values located diagonally in Table 5 refer to the square root of AVE
Table 5: Discriminant validity test results

\begin{tabular}{|c|c|c|c|c|}
\hline & $\begin{array}{c}\text { EC } \\
(\mathbf{1})\end{array}$ & $\begin{array}{c}\text { IEM } \\
(\mathbf{2})\end{array}$ & $\begin{array}{c}\text { ED } \\
(\mathbf{3})\end{array}$ & $\begin{array}{c}\text { CPB } \\
(\mathbf{4})\end{array}$ \\
\hline$(1)$ & 0.715 & - & - & - \\
\hline$(2)$ & 0.510 & 0.763 & - & - \\
\hline$(3)$ & 0.444 & 0.577 & 0.753 & - \\
\hline$(4)$ & 0.661 & 0.547 & 0.395 & 0.740 \\
\hline
\end{tabular}

*EC: Environmental Concern, IEM: Internal Environmental Management image, ED: Eco-Design, CPB: Consumer Purchasing (eco-friendly product) Behavior

values. All the square root of AVE values were larger than the correlation coefficients; the discrimination validity was therefore secured.

\subsection{Empirical Analysis}

Hypothesis testing was performed on the effect of environmental concerns on consumer purchasing behavior mediated by the image of internal GSCM practices. Structural model analysis using the maximum likelihood method revealed the model fit was CMIN / DF $=1.790, \mathrm{RMR}$ $=0.053, \mathrm{GFI}=0.955, \mathrm{CFI}=0.975, \mathrm{TLI}=0.965, \mathrm{RMSEA}$ $=0.051$, indicating that the acceptable criteria presented by Hair et al. (2010) were generally met. Table 6 presents the results of hypotheses testing through path analysis.

The results of the hypothesis test indicated that Hypotheses 1 and 2 were adopted. This means that environmental concern has a significant effect on the internal environmental management image and eco-design image, which are main factors of the internal GSCM practice. This result is consistent with previous research findings that environmental concern affects the internal organization and operational strategy within a company. Further, internal environmental management image and eco-design image were found to have a significant impact on consumer purchasing behavior. Thus, Hypothesis 3 and 4 were adopted. These results are also consistent with the previous studies' findings that consumers are increasing their interest in internal activities beyond external activities of the company. These results implicate

Table 6: Hypotheses testing results

\begin{tabular}{|l|c|c|c|c|c|}
\hline Hypothesis testing & Estimate & S.E. & C.R. & P & Analysis results \\
\hline Hypothesis 1 & 0.694 & 0.104 & 6.693 & $<0.001\left(^{* * *}\right)$ & Accepted \\
\hline Hypothesis 2 & 0.601 & 0.103 & 5.839 & $<0.001\left(^{* * *}\right)$ & Accepted \\
\hline Hypothesis 3 & 2.179 & 0.469 & 4.643 & $<0.001\left(^{* * *}\right)$ & Accepted \\
\hline Hypothesis 4 & -0.784 & 0.299 & -2.621 & $0.009\left(^{* *}\right)$ & Accepted \\
\hline
\end{tabular}

${ }^{*} \mathrm{P}<0.05,{ }^{* *} \mathrm{P}<0.01,{ }^{* * *} \mathrm{P}<0.001$ 
a point to distinguish from the existing paper, because the current study verified that company's internal GSCM image could affect the purchasing decision of the end consumer, which is a downstream end in SCM.

\section{Discussion and Conclusion}

\subsection{Discussion}

This study verified the impact of environmental concerns on consumer purchasing behavior mediated by the company image of internal GSCM practices. As environmental concerns increase, the company's environmental image strategy for environmental improvements has become an inevitable task. Reflecting this trend, companies have built eco-friendly images through advertisements and media and have induced consumer purchasing behavior and wordof-mouth communication. However, eco-friendly image advertisements and propaganda no longer move consumers, and the purchase rate was overwhelmingly low for ecofriendly products compared to the increase in environmental concerns because of consumer distrust and skepticism. As environmental concerns grow, more sincere environmental efforts will be required. Therefore, it is time for a new approach to increase consumer purchasing behavior, which should eliminate disbelief about a company's eco-friendly image and raise consumer's knowledge of its eco-friendly products. This study proposed the establishment of the image of internal GSCM practices as a solution. GSCM has been a representative B2B field measured internally among suppliers, manufacturers, and vendors. However, as consumers search deeper into a company's internal practices, the internal GSCM image can become an honest approach and new strategy for building the company's ecofriendly image. GSCM, which was measured integrally, was divided into internal and external practices (Zhu et al., 2013), and only the internal practice was selected for this research. The research model was developed based on the logic of previous studies, and the causal relationships between Hypotheses 1 through 4 were verified through path analysis.

The first hypothesis examined whether environmental concerns have a positive effect on the internal environmental management image, which is a factor of internal GSCM practice. Environmental concerns affect the company's ecofriendly activities and image. In addition, improvements in the internal environmental management image are only possible with the dedication and support of the company's top management, middle- and high-level managers, and cross-functional cooperation departments. Hypothesis 1, which states that consumers' environmental concerns have a positive effect on the company's internal environmental management image, was accepted.
Hypothesis 2 examined whether environmental concerns have a positive effect on eco-design image. Eco-design is a representative internal GSCM practice that is closely linked to internal environmental management and is the stage with the most direct impact on the environment. In particular, eco-design visualizes the process of producing eco-friendly products, and it was judged as a factor that can raise consumers' product knowledge and eliminate distrust of the company's eco-friendly image. Hypothesis 2 was also accepted, which implies that the company can further promote and develop its GSCM by investing in the production of ecofriendly products and process development to establish its eco-friendly image.

Hypothesis 3, which states that the company's internal environmental management image has a positive effect on consumer purchasing behavior, was also accepted. Efforts, support, and management for environmental protection by internal managers is the first gateway to successful GSCM. Environmental support and cooperation from the middleand upper-managerial levels are key factors in determining the success or failure of internal GSCM practices. Internal environmental management goes beyond the environmentally friendly attitudes of internal employees and includes the environmental philosophy and values pursued by the company. Thus, such management influences the company's eco-friendly image. The finding that the internal environmental management positively affects consumer purchasing behavior suggests that the company should aim to build an internal culture that prioritizes the environment in the future. It also implies that the company's environmental philosophy and values may then be reflected in consumer purchasing behavior.

Hypothesis 4, which states that the company's eco-design image has a positive effect on consumer purchasing behavior, was also accepted. The phenomenon of consumers who do not purchase eco-friendly products despite the increased global environmental concern was explained by the "gap between attitude/purchase." It was predicted that excessive advertising and media activities for building an ecofriendly image is one of the factors that hinders consumers' purchases. By accepting Hypothesis 4, the company's ecofriendly activities can be promoted by focusing on building an eco-design image rather than relying on advertising to build an environmentally-friendly image. The company's internal investments and practices will result in a competitive advantage, leading to consumers purchasing its products.

\subsection{Implications}

It was confirmed that environmental concerns would affect consumer purchasing behavior mediated by the image of internal GSCM practices. A review of previous studies identified the following limitations. 
First, most of the previous studies on internal GSCM practices were limited to internal employees. Most studies related to GSCM used the company's organizational (Zhu $\&$ Sarkis, 2004) or the environmental, social, and economic performance (Green et al., 2012; Lee, 2014; Lee \& Ha, 2020; Pinto, 2019) as the dependent variable. It is assumed that the consumer's perspective was excluded because GSCM is a typical B2B domain. However, it is clear that the end point of the supply chain structure is the end consumer, and a company that is not selected by consumers will be unable to survive. Even if a company successfully implements internal GSCM practices, it will not be of significance unless the consumers purchasing their products know of their internal GSCM practices. The results implied that internal GSCM practices must be a factor that is evaluated by the end users, rather than being measured by internal employees. The current study expanded the fixed frame that GSCM should only be measured within the B2B industry and has academic implications in that it measured internal GSCM practice from the consumer's perspective.

Secondly, most of the previous studies on eco-friendly products and consumer purchasing behavior focused on organic food categories (Kim \& Chung, 2011) and expanded purchase product categories to personal care products and organic cosmetic products (Nguyen, Nguyen, \& Vo, 2019). Kim and Chung (2011) found that in the US organic industry, the personal care market had the second largest sales after food products, but most previous studies only focused on food products and the marketing perspective. They differentiated from previous studies by focusing on consumer goods and consumer purchasing behavior. Liobikienè et al. (2016) also found that most previous studies focused on organic foods with only a few handling general consumer goods, cosmetics, and household appliances. It is firmly believed that eco-friendly products will be launched in various fields beyond the food industry. This study attempted to overcome the limitations of previous studies by expanding the survey to include general products.

Lastly, most studies related to consumer behavior were conducted in developed countries such as the United States and the United Kingdom. Yadav and Pathak (2017) argued that because consumption of green products is rapidly spreading in developed countries, it is essential for developing countries to acquire an understanding from an eco-friendly consumer perspective to create a platform for the future. Studies on developing countries included India, Brazil, Taiwan, Malaysia, Brazil, Indonesia, and China (Liobikienè et al., 2016), but few have been conducted on Korean consumers. Liobikienè et al. (2016) found that most studies related to eco-friendliness concentrated on consumer purchasing behaviors in developed countries, and the authors focused on the EU to differentiate their study. It was challenging to find studies that examined the causal relationship between a company's internal activities such as GSCM and consumer purchasing behavior. Cho, Bonn, and Kang (2015) examined the effects of GSCM practice on the purchase intention of the general consumer but the category was limited to organic food.

To overcome the limitations of previous studies, this study provided academic implications by focusing on the internal GSCM activities for general consumers in Korea, which is a developing country.

\subsection{Limitations and Suggestions for Further Research}

This section outlines the limitations of this study and offers suggestions for future research. First, other factors that can cause environmental concerns to lead to consumer purchasing behavior were excluded. To differentiate from existing studies, the internal GSCM image was examined from the consumer's perspective rather than that of internal employees. However, if demographic factors such as consumer's age, gender, occupation, and income were applied as control variables, the characteristics and meanings of the factors affecting the dependent variable could have been more accurately identified and understood. Second, the average consumer surveyed lacked professional expertise and information on companies' internal GSCM practices. This is a limitation as it poses the question of whether evaluations by ordinary consumers can realistically reflect the company's operational strategy, without considering the size or expertise of the company. However, the results have many implications in that the company image of internal GSCM practices, which the consumer had not considered in selecting a product, impacts purchase behavior. Internal GSCM practices can increase the environmental knowledge and interest of the product production process from the consumer's perspective, so that, companies will be more active in the adoption of GSCM from the perspective of corporate employees because it will create an additional observer - the consumer - in addition to the employees. This differentiation strategy can be used to approach consumers along with the eco-friendly image. This study investigated only two factors of internal GSCM practices based on previous studies. Further expansion of the factors for internal GSCM practices will lead to clearer considerations. Furthermore, it will be necessary to make efforts for ecofriendly development not only in the GSCM area, but also in other areas that are conducted internally within the company.

\subsection{Conclusion}

Ethical and eco-friendly consumption is no longer limited to developed countries. In Korea, consumers' perceptions and purchasing behaviors are changing as environmental 
concerns increase. Reflecting this trend, most studies have focused on eco-friendly consumers. However, previous studies targeting general consumer purchasing behavior of eco-friendly products were limited. Based on the results of this study, it is expected that purchasing behavior initiated by environmental concern will affect consumer purchasing behavior. Internal GSCM practices were hidden from general consumers. Internal GSCM image will be a sustainable strategy for companies to highlight the eco-friendly image and induce general consumer purchasing behavior.

In anticipation of this trend, companies will be required to adopt and implement GSCM as a consumer-oriented motive, rather than because of government regulations or external pressure. In the future, consumers will no longer choose products because of environmentally-friendly image advertisements or media. Going forward, the company's ecofriendly image should be built with the dedication and effort of internal employees, reflecting on the company's philosophy to improve the environment, accompanied by the development and innovation of products and processes to create ecofriendly products. Consumers will choose companies with such a strategy and operation with environmental concerns, and this will become the companies' competitive advantage.

\section{References}

Albayrak, T., Aksoy, Ş., \& Caber, M. (2013). The effect of environmental concern and skepticism on green purchase behavior. Marketing Intelligence \& Planning, 31(1), 27-39.

Bang, H. K., Ellinger, A. E., Hadjimarcou, J., \& Traichal, P. A. (2000). Consumer concern, knowledge, belief, and attitude toward renewable energy: An application of the reasoned action theory. Psychology \& Marketing, 17(6), 449-468.

Berchicci, L., \& Bodewes, W. (2005). Bridging environmental issues with new product development. Business Strategy and the Environment, 14(5), 272-285.

Carter, C. R., \& Rogers, D. S. (2008). A framework of sustainable supply chain management: Moving toward new theory. International Journal of Physical Distribution \& Logistics Management, 38(5), 360-387.

Chan, R. Y. (2001). Determinants of Chinese consumers' green purchase behavior. Psychology \& Marketing, 18(4), 389-413.

Chen, Y. S. (2008). The driver of green innovation and green image-green core competence. Journal of Business Ethics, $81(3), 531-543$.

Chen, Y. S. (2010). The drivers of green brand equity: Green brand image, green satisfaction, and green trust. Journal of Business Ethics, 93(2), 307-319.

Chin, T. A., Tat, H. H., \& Sulaiman, Z. (2015). Green supply chain management, environmental collaboration and sustainability performance. Procedia Cirp, 26, 695-699.
Cho, M., Bonn, M. A., \& Kang, S. (2015). The moderating effects of retailers' green practices upon customer environmental values and organic food purchasing intention. Journal of Distribution Science, 13(11), 5-13.

Choi, B. N., Lee, H. H., \& Yang, H. C. (2014). Impacts of value inclination and self-expressive consuming propensity upon eco-friendly product purchasing intention. The Journal of Business, Economics and Environmental Studies, 4(4), 39-49.

Czap, N. V., \& Czap, H. J. (2010). An experimental investigation of revealed environmental concern. Ecological Economics, 69(10), 2033-2041.

D'souza, C., \& Taghian, M. (2005). Green advertising effects on attitude and choice of advertising themes. Asia Pacific Journal of Marketing and Logistics, 17(4), 51-66.

Gollagher, M., Sarkis, J., Zhu, Q., Geng, Y., Fujita, T., \& Hashimoto, S. (2010). Green supply chain management in leading manufacturers. Management Research Review, 33(4), 380-392.

González, P., Sarkis, J., \& Adenso-Díaz, B. (2008). Environmental management system certification and its influence on corporate practices. International Journal of Operations \& Production Management, 28(11), 1021-1041.

Green Jr, K. W., Zelbst, P. J., Meacham, J., \& Bhadauria, V. S. (2012). Green supply chain management practices: Impact on performance. Supply Chain Management: An International Journal, 17(3), 290-305.

Gunasekaran, A., Lai, K. H., \& Cheng, T. E. (2008). Responsive supply chain: A competitive strategy in a networked economy. Omega, 36(4), 549-564.

Gupta, S., \& Ogden, D. T. (2009). To buy or not to buy? A social dilemma perspective on green buying. Journal of Consumer Marketing, 26(6), 376-391.

Hair, J. F., Black, W. C., Babin, B. J., \& Anderson, R. E. (2010). Multivariate data analysis, Englewood Cliff NJ: Prentice Hall.

Han, H., \& Kim, Y. (2010). An investigation of green hotel customers' decision formation: Developing an extended model of the theory of planned behavior. International Journal of Hospitality Management, 29(4), 659-668.

Hartmann, P., \& Apaolaza-Ibáñez, V. (2012). Consumer attitude and purchase intention toward green energy brands: The roles of psychological benefits and environmental concern. Journal of Business Research, 65(9), 1254-1263.

Ho, J. C., Shalishali, M. K., Tseng, T., \& Ang, D. S. (2009). Opportunities in green supply chain management. The Coastal Business Journal, 8(1), 18-31.

Im, M. J., Song, M. R., \& Chu, W. J. (2019). Effects of consumer innovativeness on environment-friendly product satisfaction. Journal of Distribution Science, 17, 125-134.

Junior, S. B., Da Silva, D., Gabriel, M. L. D., \& De Oliveira Braga, W.R. (2015). The effects of environmental concern on purchase 
of green products in retail. Procedia-Social and Behavioral Sciences, 170, 99-108.

Jung, Y. S. (2015). FedEx earth smart: Practices of environmentfriendly management. Journal of Economics, Marketing and Management, 3(4), 21-27.

Kilbourne, W., \& Pickett, G. (2008). How materialism affects environmental beliefs, concern, and environmentally responsible behavior. Journal of Business Research, 61(9), 885-893.

Kim, H. Y., \& Chung, J. E. (2011). Consumer purchase intention for organic personal care products. Journal of Consumer Marketing, 28(1), 40-47.

Knight, P., \& Jenkins, J. O. (2009). Adopting and applying ecodesign techniques: A practitioner's perspective. Journal of Cleaner Production, 17(5), 549-558.

Lai, K., Cheng, T. C. E., \& Yeung, A. C. L. (2005). Relationship stability and supplier commitment to quality. International Journal of Production Economics, 96(3), 397-410.

Lee, C., \& Ha, B. C. (2020). The Impact of Interactional Justice and Supply-Chain Collaboration on Sustainable SCM Performance: The Case of Multinational Pharmaceutical Firms. The Journal of Asian Finance, Economics and Business. 7(2), 237-247.

Lee, H. S., \& Hong, S. T. (2019). Revisiting of greenness to consumers in green purchases. Journal of Distribution Science, 17(10), 107-114.

Lee, H. S. (2016). Do ethical consumers really love green brand? A comparison of Chinese and Korean consumers. Journal of Distribution Science, 14(12), 23-30.

Lee, J. W. (2014). The impact of product distribution and information technology on carbon emissions and economic growth: Empirical evidence in Korea. Journal of Asian Finance, Economics and Business, 1(3), 17-28.

Lee, K. (2008). Opportunities for green marketing: Young consumers. Marketing Intelligence \& Planning, 26(6), 573-586.

Lewis, G. J., \& Harvey, B. (2001). Perceived environmental uncertainty: The extension of Miller's scale to the natural environment. Journal of Management Studies, 38(2), 201-234.

Lin, P. C., \& Huang, Y. H. (2012). The influence factors on choice behavior regarding green products based on the theory of consumption values. Journal of Cleaner Production, 22(1), 1118 .

Liobikienė, G., Mandravickaitè, J., \& Bernatonienè, J. (2016). Theory of planned behavior approach to understand the green purchasing behavior in the EU: A cross-cultural study. Ecological Economics, 125, 38-46.

Moisander, J. (2007). Motivational complexity of green consumerism. International Journal of Consumer Studies, 31(4), 404-409.

Moser, A. K. (2015). Thinking green, buying green? Drivers of pro-environmental purchasing behavior. Journal of Consumer Marketing, 32(3), 167-175.
Nguyen, P. N. D., Nguyen, V. T., \& Vo, N. N. T. (2019). Key Determinants of Repurchase Intention toward Organic Cosmetics. The Journal of Asian Finance, Economics and Business, 6(3), 205-214.

Nielsen (2019). Identifying unique sustainability opportunities across categories to foster trust with consumers. New York, USA. Retrieved February 20, 2020, from https://www. nielsen.com/us/en/insights/article/2019/identifying-uniquesustainability-opportunities-across-categories-to-foster-trustwith-consumers/

Pinto, L. (2019). Social supply chain practices and companies performance: An analysis of Portuguese industry. Journal of Distribution Science, 17(11), 53-62.

Saifullah, M. K., Kari, F. B., \& Ali, M. A. (2017). Linkage between public policy, green technology and green products on environmental awareness in the urban Kuala Lumpur, Malaysia. The Journal of Asian Finance, Economics and Business, 4(2), 45-53.

Sarkis, J., Zhu, Q., \& Lai, K. H. (2011). An organizational theoretic review of green supply chain management literature. International Journal of Production Economics, 130(1), 1-15.

Seuring, S., \& Müller, M. (2008). From a literature review to a conceptual framework for sustainable supply chain management. Journal of Cleaner Production, 16(15), 16991710.

Srivastava, S. K. (2007). Green supply-chain management: A state-of-the-art literature review. International Journal of Management Reviews, 9(1), 53-80.

Suki, N. M. (2016). Consumer environmental concern and green product purchase in Malaysia: Structural effects of consumption values. Journal of Cleaner Production, 132, 204-214.

Su, S., Jeong, Y. J., Choi, J. Y., \& Kim, S. W. (2015). Effects of ethical management of retail enterprises in Korea on corporate image and purchase intention. The Journal of Business, Economics and Environmental Studies, 5(1), 27-35.

Thieme, J., Royne, M. B., Jha, S., Levy, M., \& McEntee, W. B. (2015). Factors affecting the relationship between environmental concern and behaviors. Marketing Intelligence \& Planning, 33(5), 675-690.

Yadav, R., \& Pathak, G. S. (2017). Determinants of consumers' green purchase behavior in a developing nation: Applying and extending the theory of planned behavior. Ecological Economics, 134, 114-122.

Zhu, Q., \& Sarkis, J. (2004). Relationships between operational practices and performance among early adopters of green supply chain management practices in Chinese manufacturing enterprises. Journal of Operations Management, 22(3), 265289.

Zhu, Q., Sarkis, J., \& Geng, Y. (2005). Green supply chain management in China: Pressures, practices and performance. International Journal of Operations \& Production Management, 23(5), 449-468. 
Zhu, Q., Sarkis, J., Cordeiro, J. J., \& Lai, K. H. (2008a). Firmlevel correlates of emergent green supply chain management practices in the Chinese context. Omega, 36(4), 577-591.

Zhu, Q., Sarkis, J., \& Lai, K. H. (2008b). Confirmation of a measurement model for green supply chain management practices implementation. International Journal of Production Economics, 111(2), 261-273.
Zhu, Q., Sarkis, J., \& Lai, K. H. (2013). Institutional-based antecedents and performance outcomes of internal and external green supply chain management practices. Journal of Purchasing and Supply Management, 19(2), 106-117.

Zhu, Q., Sarkis, J., \& Lai, K. H. (2019). Choosing the right approach to green your supply chains. Modern Supply Chain Research and Applications, 1(1), 54-67. 